\title{
Effect of Employee Communication on Organisation Performance in Kenya's Horticultural Sector
}

\author{
Brenda Beryl Achieng Otieno ${ }^{1}$, Esther Wangithi Waiganjo ${ }^{1} \&$ Agnes Njeru $^{1}$ \\ ${ }^{1}$ School of Human Resource Development, Jomo Kenyatta University of Agriculture \& Technology, Nairobi, Kenya \\ Correspondence: Brenda Beryl Achieng Otieno, Business Administration, School of Human Resource Development, \\ Jomo Kenyatta University of Agriculture \& Technology, Nairobi, Kenya. E-mail: achieng1573@gmail.com
}

Received: February 2, 2015

Accepted: February 26, 2015

Online Published: March 14, 2015

doi:10.5430/ijba.v6n2p138

URL: http://dx.doi.org/10.5430/ijba.v6n2p138

\begin{abstract}
The horticulture sector is estimated to employ over 50,000-60,000 people directly and 500,000 people indirectly through affiliated services to the industry for example farm inputs, transport, packaging and banking (Kenya Flower Council, 2010). It is therefore imperative that the welfare of the workers working in this sector is given paramount importance by both government and the stakeholders as a whole. This study therefore sought to explore the effect of employee communication on organization performance in Kenya's horticultural sector. This study was carried out in flower farms in Kenya. The population of this study was all flower farms in Kenya which were the 14 flower farms registered in the KFC directory (2013) and based in Naivasha. The study targeted the employees in the identified farms. Cross sectional survey research design was used for the study. Stratified sampling technique was used to sample the study respondents. A total of 2460 respondents were targeted by the study out of which 1888 responded giving a response rate of $76.7 \%$. Questionnaires were used as instrument for data collection. Both quantitative and qualitative data analysis techniques were used. Quantitative data was analyzed using descriptive statistics while qualitative data was analyzed thematically. Inferential statistics such as correlation and regression analysis were used to test on the relationship between the variables of the study. The study found that $65 \%$ of the respondents strongly agreed that communication facilitates exchange of information and opinion with the organization. It was also found that that $63 \%$ of the respondents were found by the study to agree that communication helps in improving operational efficiency thus improving organization performance. The results of correlation analysis show that employee communication is statistically significant with a Pearson correlation coefficient of 0.466 at a level of significance of 0.000 . The study concluded that employee communication is a major determinant of organization performance in the horticultural sector in Kenya. The study recommended that organizations should develop effective communication strategies. This will facilitate passing of information both within and outside the organization thus improving performance.
\end{abstract}

Keywords: employee communication, organization performance

\section{Introduction}

The history of the export of fresh horticultural produce from Kenya dates back to the period before independence when Kenya, then a British colony, was required to contribute to the running of the budget for East Africa. After independence the industry continued to flourish with exports starting to go to Europe and thus opening up the potential for Kenya in the export market (Maplecroft, 2010). Kenya is primarily an agricultural economy. Agriculture plays a critical role in national economic growth and development. The major roles of agriculture include; employment, foreign exchange creation and overall contribution to Gross Domestic Product (GDP).

Kenya is primarily an agricultural economy. Agriculture plays a critical role in national economic growth and development. The major roles of agriculture include employment, foreign exchange creation and overall contribution to GDP. Agriculture accounts for about $24 \%$ of Kenya's GDP with an estimated $75 \%$ of the population depending on the sector either directly or indirectly (Maplecroft, 2010). Agriculture is the mainstay of the Kenyan economy and currently represents 24 per cent of GDP. More than one-third of Kenya's agricultural produce is exported, and this accounts for sixty five per cent of Kenya's total exports (Dolan, 2004). The agricultural sector accounts for eighteen per cent of total formal employment in the country. The Cut-Flower Industry has been active in Kenya since the 1980's, but only in the 1990's has it transformed into a major player in the international market. 
Several factors made Kenya attractive for growing flowers: a cheap and relatively educated labour force, suitable climate conditions and proximity to Europe's big markets. These factors attracted capital and the knowledge needed for boosting the industry (Maplecroft, 2010). Today, the Cut-Flower Industry is the fastest growing segment in Kenya. It is also the largest export industry in the country responsible for annual turnover of nearly 600 Million Dollars. Kenya is the fifth largest flower exporter in the world. It exports primarily to the Netherlands, Germany and the U.K. The development of the flower industry in Kenya is an example of regional economic development that exploits comparative advantages to export to developed markets (Derek, 2005).

Companies in the horticultural sector are now increasingly coming under pressure to ensure decent working conditions for their workers. The horticulture sector is under threat from the above factors and it is imperative that attention must be shifted to address the labour relations practices in this industry since competitiveness in this sector if it is to remain the mainstream of foreign exchange earnings for the government and continue creating employment for the country. This research assessed the effect of employee communication on organization performance in Kenya's horticultural sector.

\subsection{Statement of the Problem}

The horticulture sector is estimated to employ over 50,000-60,000 people directly and 500,000 people indirectly through affiliated services to the industry for example farm inputs, transport, packaging and banking (Kenya Flower Council, 2010). It is therefore imperative that the welfare of the workers working in this sector is given paramount importance by both government and the stakeholders as a whole.

According to Maplecroft (2010), there have been poor human resource management practices in the horticultural sector as a result of companies ignoring labour relations practices. Some of these poor practices include unethical labour practices, for example dismissal of workers, without proper reasons and denying them the freedom of association by refusing them to join trade unions. The horticultural sector is now increasingly coming under pressure to ensure decent working conditions for their workers.

A research by Dolan (2004) focused on poor labour practices and environmentally damaging production processes without getting into the reason why employers were guilty of such poor practices and the effect that arose to both employees and employers as a result of such actions. Suffice to say the researcher tried to analyze how ethical trade can enhance the economic and social rights of women and men in African export Horticulture and identifying best practice in implementing gender sensitive ethical trade based on worker and stakeholder participation. Collinson (2010) research mainly focused on the gains of labour productivity and management efficiency arising from implementation of social codes in a company. Again, it did not analyze the relationship between labour relations practices in the horticulture sector. Other researchers (Omwega, 2007; Riungu, 2006; Riungu, 2007; Barrientos et al., 2003; Opondo et al, 2003; Utling, 2002) have also researched on various areas within the flower industry including gender rights, multi stakeholder participation and working conditions in the industry. Going through these researches there is a gap on the relationship between labour relations practices in the horticulture sector. This study therefore sought to assess the effect of employee communication on organization performance in Kenya's horticultural sector.

\section{Literature Review}

This section presents theoretical and empirical review.

\subsection{Human Capital Theory}

The concept of Human capital has relatively more importance in labour-surplus countries. These countries are naturally endowed with more of labour due to high birth rate under the given climatic conditions (House, 1996). The surplus labour in these countries is the human resource available in more abundance than the tangible capital resource. According to Kelly (2007) this human resource can be transformed into human capital with effective inputs of education, health and moral values. The transformation of raw human resource into highly productive human resource with these inputs is the process of human capital formation. The problem of scarcity of tangible capital in the labour surplus countries can be resolved by accelerating the rate of human capital formation with both private and public investment in education and health sectors of their National economies.

The tangible financial capital is an effective instrument of promoting economic growth of the nation. The intangible human capital, on the other hand, is an instrument of promoting comprehensive development of the nation because human capital is directly related to human development, and when there is human development, the qualitative and quantitative progress of the nation is inevitable. Human capital is the stock of competencies, knowledge, social and personality attributes, including creativity, cognitive abilities, embodied in the ability to perform labor so as to produce economic value. It is an aggregate economic view of the human being acting within economies, which is an attempt to 
capture the social, biological, cultural and psychological complexity as they interact in explicit and/or economic transactions (Rosen, 1987).

Many theories explicitly connect investment in human capital development to education, and the role of human capital in economic development, productivity growth, and innovation has frequently been cited as a justification for government subsidies for education and job skills training. There is also strong evidence that organizations that possess and cultivate their human capital outperform other organizations lacking human capital (Crook, Todd, Combs, Woehr, and Ketchen, 2011). This study assessed the relevance of this theory in relation to the organisational performance of Kenya's horticultural sector which is very labour intensive.

\subsection{Universal Theory}

The universal theory of leadership is the belief that there are certain traits that contribute to leadership effectiveness in all situations. The elements to this theory are Personal characteristics, behaviors, and skills. According Rosen (1987) the elements of the universal theory of leadership the leader has to have several traits to become an effective leader. First of all, an effective leader has to have a vision about how organization could or should be the in the future. Secondly, the leader needs to have self-confidence to become an effective leader because if the leader has great ideas without confident in himself he will not achieve anything. Also, an effective leader needs to have great skills of communication to convince others to follow him. Additionally, an effective leader needs to have humility when he treats people even though, the leader has great ideas, often most of the ideas come from someone else (Keeley, 2007). As a result, the leader has to surround himself by those people who have those ideas. However, based on the prior traits of an effective leader, we can notice the difference between management and leadership in several aspects. First of all, the manager does not have to have vision because the manager has plans and budget to follow. Secondly, the manager does not need to have to be a great communicator to convince others because he gives directions and rules that others have to follow. In other words the manger is controlling the power in the organization and enforces others to achieve their tasks. Another difference between the management and the leadership is that the manager does not need to have humility such as the leader (Cole, 2002).

However, the universal theory of leadership has a limitation because the leader may have all traits in this theory but he is not an effective leader. The reason that the theory has limitation because leadership's elements are: leader, group members, and situation. Sometimes the group members are not effective or the situation inappropriate. This theory will support the variable on leadership styles and how this impacts on organizational performance.

\subsection{Empirical Literature}

Inedegbor et al. (2012) investigated the impact of business communication on organizational performance in Nigerian companies. The study specifically investigated the relationship between business communication and organizational performance in Nigeria using a contextualized and literature based research instrument to measure the application of the investigated "constructs". Using the survey method, the study obtained sample data from 100 small and large manufacturing and service companies operating in Lagos State of Nigeria. The research instrument showed encouraging evidence of reliability and validity. Data were analyzed using descriptive statistics, percentages and t- test analysis. The study found that effective business communication is emphasized to a reasonable extent in the surveyed Nigerian companies. However, the 'level of emphasis' was a question of degree. It was also found that the extent of practices of effective business communication, were related to the category of business (service versus manufacturing) and its size. This study therefore sought to assess the effect of employee communication on organization performance in Kenya's horticultural sector.

Neves (2012) used a cross-lagged panel design to examine the temporal relationship between management communication and perceived organizational support (POS), and its consequences for performance. Assessed was done on management communication and POS 2 times, separated by a 3-year interval, in a social services organization $(N=236)$. The findings suggest that management communication was positively associated with a temporal change in POS. In addition, it was found that POS fully mediates the relationship between management communication and both in-role and extra-role performance. The study advanced the theoretical knowledge concerning how management communication affects performance, with implications for practice. Specifically, it revealed that management communication affects performance mainly because it signals that the organization cares about the well-being and values the contributions of its employees. This study also adopted the use the perceived organization support in terms of communication as indicators on the effect of communication on organization performance.

Rho (2009) assessed the impacts of organizational communication on the perception of red tape by comparing internal communication with external, especially client-oriented, communication in both public and nonprofit organizations. 
This study was based on the questionnaire data from the National Administration Studies Project (NASP)-III, closed in January 2006, gathered from a survey of public and nonprofit managers in the states of Illinois and Georgia. Results showed that frequent communication with clients plays an important role in reducing perceived red tape, and sector-based differences between public and nonprofit sectors influence the impact of communication type on red tape perception. The analysis controls for the organizational characteristics, job characteristics, and personal characteristics. This study looked at the effect of the use of communication as a tool on the general performance of organizations in the horticultural sector in Kenya.

\section{Methodology}

This study was carried out in flower farms in Kenya. The population of this study was all flower farms in Kenya which were the 14 flower farms registered in the KFC directory (2013) and based in Naivasha. The study targeted the employees in the identified farms. Cross sectional survey research design was used for the study. Stratified sampling technique was used to sample the study respondents. A total of 2460 respondents were targeted by the study out of which 1888 responded giving a response rate of $76.7 \%$. Questionnaires were used as instrument for data collection. Both quantitative and qualitative data analysis techniques were used. Quantitative data was analyzed using descriptive statistics while qualitative data was analyzed thematically. Inferential statistics such as correlation and regression analysis were used to test on the relationship between the variables of the study.

Multiple regression model presented below was used

$$
Y=\beta_{0}+\beta_{1} X_{1}+\beta_{2} X_{2}+\beta_{3} X_{3}+\beta_{1} X_{1} Z+\varepsilon
$$

Where

$\mathrm{Y}=$ is the dependent variable (Organizational performance)

$\mathrm{Z}=$ Leadership styles

$\mathrm{Xi}=$ is the three independent variables i.e. employee communication, employee involvement and human resources procedures where $(\mathrm{i}=1,2, \ldots . \mathrm{n})$

$\mathrm{X}_{1}=$ Employee communication

$\mathrm{X}_{2}=$ Employee engagement

$\mathrm{X}_{3=}$ Human resource procedures

$\mathrm{z}=$ product term between moderating variables and each independent term

$\beta_{\mathrm{i}(\mathrm{i}=1,2,3,4)}$ are the parameters associated with the corresponding independent variable that are to form part of the partial regression coefficients

$\beta_{0}$ is the intercept

$\varepsilon$ is the error term

\section{Findings of the Study}

The study adopted factor analysis in order to reduce the number of indicators or factors under each research variable and retain the indicators capable of explaining the responses to globalization adopted by manufacturing firms in Kenya. The retained factors had loading values of above 0.4 and were used for further analysis.

To measure the reliability of the gathered data, Cronbach's alpha was used. Cronbach's alpha is a coefficient of reliability that gives an unbiased estimate of data generalizability (Zinberg, 2005). An alpha coefficient of 0.70 or higher indicated that the gathered data is reliable as it has a relatively high internal consistency and can be generalized to reflect opinions of all respondents in the target population (Zinbarg, 2005). Table 1 shows Cronbach's alpha of all indicators. Cronbach's alpha results in the component column were computed using the results of all indicators. The results revealed that one of the indicators had a loading less than 0.4 . 
Table 1. Factor analysis for employee communication indicators

\begin{tabular}{clcc}
\hline $\begin{array}{c}\text { Cronbach's } \\
\text { Alpha before }\end{array}$ & Component & $\begin{array}{c}\text { Cronbach } \\
\text { Alpha after }\end{array}$ \\
\hline .807 & $\begin{array}{l}\text { Communication helps in improving teamwork thus } \\
\text { decreasing grievances }\end{array}$ & .807 & .816 \\
\hline $\begin{array}{l}\text { Communication boosts employee morale thus improving } \\
\text { their job performance }\end{array}$ & .795 & .765 \\
\hline $\begin{array}{l}\text { Communication improves job satisfaction among } \\
\text { employee thus improving organization performance }\end{array}$ & .760 \\
\hline $\begin{array}{l}\text { Communication helps in improving operational efficiency } \\
\text { thus improving organization performance }\end{array}$ & .651 \\
\hline $\begin{array}{l}\text { Communication helps in execution of decisions and } \\
\text { accomplishing tasks }\end{array}$ & .567 \\
\hline $\begin{array}{l}\text { Communication in improving public credibility and } \\
\text { corporate image }\end{array}$ & .399 \\
\hline $\begin{array}{l}\text { Communication facilitates exchange of information and } \\
\text { opinion within the organization }\end{array}$
\end{tabular}

Table 1 shows that Cronbach's alpha result of all employee communication indicators was 0.807 and the factor loading results were between 0.399 and 0.807 . This implies that six of the seven indicators were retained for further analysis. Using the retained employee communication indicators, the value of Cronbach's alpha was computed again and generated a value of 0.816 . This indicated that data collected using all the employee communication indicator values were reliable since the Cronbach's alpha value was above 0.70 . These indicators were later used for further analysis.

Descriptive statistics were used to describe the basic features of the data in the study. They provide simple summaries of the sample and measures. Descriptive statistics such as frequencies and percentages were used to analyze the data. Table 2 presents the findings on the effect of employee communication on organization performance.

Table 2. Effect of employee communication on organization performance

\begin{tabular}{lccccc}
\hline Statement & $\begin{array}{c}\text { Strongly } \\
\text { disagree }\end{array}$ & $\begin{array}{c}\text { Disagr } \\
\text { ee }\end{array}$ & $\begin{array}{c}\text { Neither } \\
\text { agree nor } \\
\text { disagree }\end{array}$ & Agree & $\begin{array}{c}\text { Strongly } \\
\text { agree }\end{array}$ \\
\hline $\begin{array}{l}\text { Communication facilitates exchange of } \\
\text { information and opinion within the } \\
\text { organization }\end{array}$ & $0 \%$ & $0 \%$ & $0 \%$ & $35 \%$ & $65 \%$ \\
\hline $\begin{array}{l}\text { Communication helps in execution of } \\
\text { decisions and accomplishing tasks }\end{array}$ & $0 \%$ & $0 \%$ & $5 \%$ & $55 \%$ & $40 \%$ \\
\hline $\begin{array}{l}\text { Communication boosts employee morale } \\
\text { thus improving their job performance }\end{array}$ & $0 \%$ & $0 \%$ & $5 \%$ & $45 \%$ & $50 \%$ \\
\hline $\begin{array}{l}\text { Communication in improving public } \\
\text { rredibility and corporate image }\end{array}$ & $1 \%$ & $1 \%$ & $3 \%$ & $54 \%$ & $41 \%$ \\
\hline $\begin{array}{l}\text { Communication helps in improving } \\
\text { operational efficiency thus improving } \\
\text { organization performance }\end{array}$ & $0 \%$ & $1 \%$ & $5 \%$ & $63 \%$ & $31 \%$ \\
\hline $\begin{array}{l}\text { Communication improves job satisfaction } \\
\text { among employee thus improving } \\
\text { organization performance }\end{array}$ & $0 \%$ & $11 \%$ & $8 \%$ & $47 \%$ & $34 \%$ \\
\hline $\begin{array}{l}\text { Communication helps in improving } \\
\text { teamwork thus decreasing grievances }\end{array}$ & $0 \%$ & $1 \%$ & $29 \%$ & $44 \%$ & $26 \%$ \\
\hline
\end{tabular}

The findings on Table 2 show that $65 \%$ of the respondents strongly agreed that communication facilitates exchange of information and opinion with the organization. It was also found that that $63 \%$ of the respondents were found by the study to agree that communication helps in improving operational efficiency thus improving organization performance, 
$55 \%$ of the respondents agreed that communication helps in execution of decisions and accomplishing of work and that $44 \%$ of the respondents also agreed that communication help in improving teamwork thus decreasing grievances.

\subsection{Correlation Analysis}

This study conducted correlation analysis to test on the strength of association/relationship between the study variables. Correlation is a measure of the relationship or association between two continuous numeric variables. It indicates both the direction and degree to which they vary with one another from case to case without implying that one is causing the other. Correlation analysis results give a correlation coefficient which measures the linear association between two variables (Crossman, 2013).

\section{Employee Communication Correlation Analysis}

The symmetric matrix with Pearson correlations given in Table 3 shows that the Pearson correlation coefficient was 0.466 and this demonstrates that employee communication have a positive correlation with globalization.

Table 3. Employee communication and organization performance

\begin{tabular}{|c|c|c|c|}
\hline \multicolumn{4}{|c|}{ Correlations } \\
\hline & & Employee Communication & Organization Performance \\
\hline \multirow{3}{*}{$\begin{array}{l}\text { Employee } \\
\text { Communication }\end{array}$} & Pearson Correlation & 1 & $.466^{* *}$ \\
\hline & Sig. (2-tailed) & & .000 \\
\hline & $\mathrm{N}$ & 1888 & 1888 \\
\hline \multirow{3}{*}{$\begin{array}{l}\text { Organization } \\
\text { Performance }\end{array}$} & Pearson Correlation & $.466^{* *}$ & 1 \\
\hline & Sig. (2-tailed) & .000 & \\
\hline & $\mathrm{N}$ & 1888 & 1888 \\
\hline
\end{tabular}

\subsection{Regression Analysis}

\section{Regression Analysis on Employee Communication and Organization Performance}

Regression analysis was done to determine the relationship between employee communication and organization performance.

Table 4 shows that the coefficient of determination $\mathrm{R}$ square is 0.217 and $\mathrm{R}$ is 0.466 at 0.05 significant level. The coefficient of determination indicates that $21.7 \%$ of the variation in the response to organization performance is explained by employee communication.

Table 4. Regression analysis on employee communication and organization performance

\begin{tabular}{lcccr}
\hline \multicolumn{5}{c}{ Model Summary } \\
\hline Model & R & R Square & Adjusted R Square & Std. Error of the Estimate \\
\hline 1 & $.466^{\text {a }}$ & .217 & .216 & .861 \\
\hline a. Predictors: (Constant), Employee Communication & & \\
\hline
\end{tabular}

Table 5 presents the results of Analysis of Variance (ANOVA) employee communication versus organization performance. The ANOVA results for regression coefficient indicates that the significance of the $F$ is 0.00 which is less than 0.05 hence implying that there is a positive significant relationship between employee communication and organization performance.

Table 5. Anova

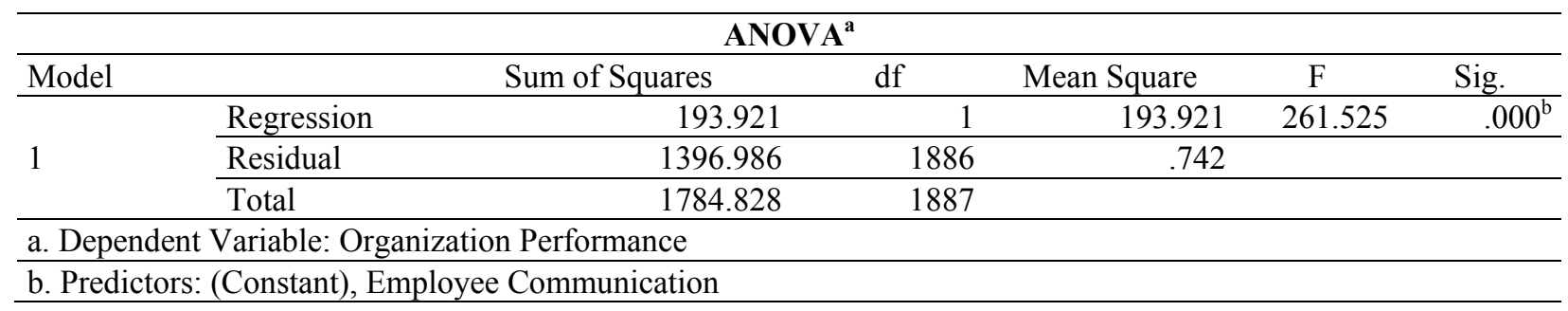


Analysis was done to determined beta coefficients of employee communication versus organization performance. Table 6 shows that there is significant relationship between employee communication and organization performance. Since the coefficient of adoption of technology is 0.793 which is statistically greater than zero. The t statistic is 16.172 which is greater than zero. This demonstrates that employee communication have a positive influence on organization performance.

Table 6. Coefficients

\begin{tabular}{|c|c|c|c|c|c|c|}
\hline \multicolumn{7}{|c|}{ Coefficients $^{\mathrm{a}}$} \\
\hline \multirow[t]{2}{*}{ Model } & & \multicolumn{2}{|c|}{ Unstandardized Coefficients } & Standardized & $\mathrm{t}$ & Sig. \\
\hline & & B & Std. Error & Beta & & \\
\hline \multirow{2}{*}{1} & (Constant) & .793 & .215 & & 3.687 & .000 \\
\hline & Employee Communication & .793 & .049 & .466 & 16.172 & .000 \\
\hline
\end{tabular}

\section{Discussion}

The factor analysis results on employee communication had an Alpha of 0.807 and the loading results between 0.399 and 0.807 . Using the retained employee communication indicators, the value of Cronbach's alpha was computed again and generated a value of 0.816 . The study therefore deduced that six out of the seven indicators of employee communication were reliable in assessing the effect of employee communication on organization performance. Employee communication indicators such as improving team work, boosting employee morale, improving job satisfaction, improving operational efficiency and execution of decisions and accomplishing tasks were later used for further analysis.

Descriptive statistics results showed that employee communication is one of the strategies by organizations in the horticultural sector to improve their performance. This is evidenced by $65 \%$ of the respondents strongly agreeing that that communication facilitates exchange of information and opinion with the organization. It was also found that $63 \%$ of the respondents agreed that communication helps in improving operational efficiency thus improving organization performance. These findings are in line with Inedegbor et al. (2012) findings that effective business communication positively affects the performance of the surveyed companies in Nigerian. A study by Neves (2012) also revealed that management communication was positively associated with a temporal change in perceived organizational support (POS). Neves study advanced the theoretical knowledge concerning how management communication affects performance, with implications for practice. Specifically, it revealed that management communication affects performance mainly because it signals that the organization cares about the well-being and values the contributions of its employees.

Pearson correlation analysis of employee communication results gave a correlation of 0.466 which demonstrated that employee communication has a positive correlation with organization performance. Regression model of employee communication versus organization performance gave a coefficient of determination of $\mathrm{R}$ square of 0.217 and $\mathrm{R}$ as 0.466 at 0.05 significant level. The coefficient of determination indicated that $21.7 \%$ of the organization performance is explained by employee communication. This implies that there exists a strong positive relationship between employee communication and organization performance

\section{Summary of Findings}

Employee engagement is one of the strategies by organizations in the horticultural sector to improve their performance. The study found that $65 \%$ of the respondents strongly agreed that communication facilitates exchange of information and opinion with the organization. It was also found that that $63 \%$ of the respondents were found by the study to agree that communication helps in improving operational efficiency thus improving organization performance, $55 \%$ of the respondents agreed that communication helps in execution of decisions and accomplishing of work and that $44 \%$ of the respondents also agreed that communication help in improving teamwork thus decreasing grievances.

The findings from the correlation analysis revealed that organization performance is positively related with the employee communication with a Pearson's correlation coefficient of $r=0.466$ and at a level of significance of 0.000 , an indication that employee communication is statistically significant with $p$ value less than 0.05 


\section{Conclusions}

Employee communication is a key determinant of organization performance. This is based on the fact that it facilitates exchange of information and opinion with the organization and that communication helps in improving operational efficiency thus improving organization performance.

\section{Recommendations}

The study also recommends that organizations should develop effective communication strategies. This will facilitate passing of information both within and outside the organization thus improving performance.

\section{Limitation of the Study}

One of the limitations of this study is that it only focused on employee communication which is one of the determinants of organization performance. Thus, the study left out other determinants of organization performance.

\section{References}

Barrietos, S., Dolan, C., \& Tallontire, A. (2003). A gendered value chain approach to codes of conduct in Africa Horticulture.

Collinson, C. (2001). The business Costs of ethical supply chain management: Kenya Flower Industry Case Study. NRI Report No.2607, project code: VO128.

Crossman, A. (2013). Convergence theory. About.com sociology. Retrieved December 04, 2013, from http://sociology.about.com/od/C_Index/g/Convergence-Theory.htm

Dolan, C. (2004). Seeking Common Ground' Multi stakeholder initiatives in Kenya Cut Flower Industry. Journal of Corporate Citizenship on Africa.

Inedegbor, M.U., Ahmed, K.O., Ganiyat, O.A., \& Rashdidat. (2012). Impact of business communication on organizational performance in Nigerian companies. Australian Journal of Business and Management Research, 2(1), 16-26.

Keeley, M. P. (2007). Turning toward death together: The functions of messages during final conversations in close relationships. Journal of Social and Personal Relationships, 24, 225-253. http://dx.doi.org/10.1177/0265407507075412

Maplecroft, B. (2010). Labour standards and Environmental Report, Q3. Maplecroft, Human rights monitoring, Maplecroft.

Neves, P. (2012). Management Communication and Employee Performance: The Contribution of Perceived Organizational Support. RoutledgeTaylor and Francis Company. Human Performance, 25, 452-464. http://dx.doi.org/10.1080/08959285.2012.721834

Omwenga, B. (2007). Kenya's Competiveness in the Floriculture Industry: A Test of Porters Competitive Advantage of Nations nodel.

Rho, E. (2009). The impact of organizational communication on public and nonprofit managers' perception of red tape. Published thesis, The University of Georgia School of Public and International Affairs Department of Public Administration and Policy.

Riungu, C. (2006). A thorn on every rose for Kenya's flower industry. The East African, Nairobi, February 21.

Riungu, C. (2007). Flower exports Flourish despite odds. The East African, Nairobi, May 21.

Utling. (2002). Regulating Business via Multi stakeholder Initiatives: A Preliminary Assessment.

Zinbarg, M. (2005). Research Methods ( $2^{\text {nd }}$ ed.). Pearson Publishers. 